\title{
Video Complexity: Describing Videos Used for Teacher Learning
}

\author{
Julie M. Amador ${ }^{1 *}$, Jode Keehr ${ }^{1}$, Abraham Wallin ${ }^{1}$, Christopher Chilton ${ }^{1}$ \\ ${ }^{1}$ University of Idaho, USA
}

Received 31 May 2019 - Revised 14 October 2019 • Accepted 22 October 2019

\begin{abstract}
Video is a common tool to support teacher learning, as it provides opportunity for reflection on teaching practices. Video clubs are one professional learning experience that integrates video, providing teachers an opportunity to collaboratively discuss videos from their teaching. However, few research studies have focused on the characteristics of videos used for teacher learning. We engaged teachers in a video club over the course of an academic year and analyzed the relationships between the videos teachers discussed and the complexity of the videos. Findings indicate teachers were less likely to select videos with higher complexity for discussion; however, they commonly discussed videos that included multiple participation structures for students. Teachers also discussed videos that included teacher questioning and scaffolding, student misconceptions, and those in which student thinking initially seemed inflexible. We provide the Video Complexity Framework for teacher educators and researchers to use to describe the complexity of the videos in teacher education.
\end{abstract}

Keywords: video, mathematics education, middle grades, mathematics teacher professional development, video club

\section{INTRODUCTION}

Video use to support teacher learning is a common practice internationally (Brophy, 2003; Christ, Arya, \& Chiu, 2017; Goldman, Pea, Barron, \& Derry, 2014). Researchers have studied the inclusion of video for teacher learning experiences, finding that video application occurs across content and contexts (Christ et al., 2017). As an example, Taylor et al. (2016) implemented videocases for science teacher professional development and found a positive effect on their analysis of practice. Across disciplines, video is often used as a representation of practice (Grossman et al., 2014) to provide teachers opportunity to view classroom happenings either from their own classrooms or from the classroom of others (Beisiegel, Mitchell, \& Hill, 2018). Various types of video have been employed to support teachers in a number of ways. Some researchers have used self-captured video to promote teacher reflection (Sherin \& Dyer, 2017), others have used video to allow for feedback on practice (Barab \& Duffy, 2000; Borko et al., 2008), and others have used video to present a problem of practice (Ball, 1996; Seago, 2004). Of the various adaptations of video to support educators, video clubs are one process used to elicit analytic thinking from teachers to support teachers' future instructional practices (Luna \& Sherin, 2017; Sherin \& Han, 2004; van Es \& Sherin, 2008).

Video clubs are a model of mathematics teacher professional development in which a group of teachers view and discuss video clips from instructional practice, with a specific objective (e.g. discourse, noticing) in mind (Luna \& Sherin, 2017). Some video club designers have focused purposefully on engaging teachers in video clubs to support their development of professional noticing (e.g. Jacobs, Lamb, \& Philipp, 2010; van Es \& Sherin, 2008). Other video club designers have supported teachers to identify and interpret students' thinking through various designs of video clubs (Beisiegel et al., 2018). In fact, Beisiegel and colleagues (2018) studied four aspects of video club design, including videos of a teacher's own practice (own-video), stock video, teacher-led meetings and facilitator-led meetings. Results indicated that the depth of teacher conversation was similar irrespective of the facilitator type (i.e. teacher-led v. facilitator-led), but they found that the video type (i.e. own-video v. stock video)

(C) 2020 by the authors; licensee Modestum Ltd., UK. This article is an open access article distributed under the terms and conditions of the Creative Commons Attribution License (http://creativecommons.org/licenses/by/4.0/).

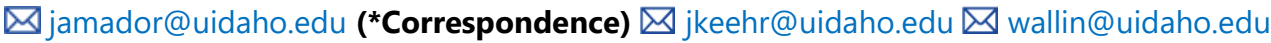




\section{Contribution of this paper to the literature}

- The Video Complexity Framework utilized in this study provides a lens for researchers and teacher educators to reference when selecting and describing video in their research.

- Videos containing teacher scaffolding and questioning, student misconceptions, or a student who was seemingly inflexible in his or her thinking, were selected for discussion by teachers more often than video without these characteristics.

- A slight correlation suggests an inverse relationship between video complexity and teachers' selection of the video; teachers tended to select less complex videos for discussion.

resulted in differences, with own-video leading to slightly more superior outcomes for in-depth discussion. The role of video type in relation to teacher learning suggests that the videos used in video clubs may influence the learning opportunities for teachers afforded in such contexts; however, few researchers have focused on characteristics of the actual videos used in teacher learning opportunities, such as video clubs.

Recently, Superfine and Bragelman (2018) provided a lens through which videos could be characterized to connect the complexity of visual and auditory elements of video with teacher noticing. Superfine and Bragelman (2018) argue that cognitive processing is associated with the intrinsic load complexity of video, meaning the depth of enacted task, clarity of children's thinking, teacher participation, and moments of children's mathematical thinking. They also argue that extraneous load dimensions are important to consider, including moments that are not focused on children's mathematical thinking, meaning peripheral audio or visual inclusions in the video. They used stock videos for use in a teacher preparation program as opposed to own-video (i.e. Beisiegel et al., 2018), and found that videos "are not all created equal in terms of the teaching and learning interactions that are made visible to the viewer" (p. 14). Superfine and Bragelman (2018) argue that additional consideration should be given to the characteristics of videos that are used to support teacher learning. This recommendation is in accordance with Sherin, Linsenmeier, and van Es (2009) who studied features of video clips that promoted mathematics teachers' discussions. They found that productive videos provide windows into students' thinking, portray depth in student mathematical thinking, and include content that is not always straightforward on the initial pass. These video features were found to promote discourse about students' thinking, yet the intricacies of the complexity of the video (i.e. video focus, audio clarity, etc.) were not explicitly studied.

Given the frequent use of video to support teacher learning, and the dearth of research on the actual characteristics of video, we argue that more attention should be given to the features of videos used. We focus on the intrinsic and extraneous load characteristics (i.e. Paas, Renkl, \& Sweller, 2003; Superfine \& Bragelman, 2018; Sweller, van Merriënboer \& Paas, 2019) of video and also consider other complexities of videos, such as whether or not the same students appear in more than one clip and whether or not multiple representations or solution strategies are apparent in a video club. In addition to building from Superfine and Bragelman's work with video complexity, we considered video characteristics in comparison to how long particular videos were discussed during a video club. Commonly, video clubs include one video (e.g. Jilk, 2016) which is shown at the beginning of the video club meeting, or they include a pattern of video viewing and discussion followed by more video viewing and more discussion (e.g. Luna \& Sherin, 2017). Although these formats have been found beneficial for teacher learning (e.g. Jilk, 2016; Luna \& Sherin, 2017; Sherin \& van Es, 2009) they have not provided opportunity for analysis on how long teachers spend discussing different videos or what videos teacher choose to discuss, if given the option. Even though the length of teachers' discussions does not provide indication about the quality of the conversation, the depth of their thinking, or their actual noticing, we consider teacher selection and discussion of videos to be an indicator of what they notice (e.g. van Es, 2011; van Es \& Sherin, 2008). Consequently knowing more about the length of time teachers spend discussing particular video clips is important to provide the field with data on the types of video teachers select to discuss. As a result, we addressed the following research questions:

1) In a video club, how does video complexity relate to the videos teachers select to write about (those that included aspects teachers noticed) and the amount of time teachers talk about a given video?

2) What are the characteristics of videos teachers discuss in a video club?

The intent of the study was to provide the mathematics education field with language to describe video complexity and to draw conclusions about the relationship between video complexity and discussions within a video club - with a focus on discussion duration as an indication of teachers' choices of what to talk about, based on what they noticed. If video continues to play a prominent role in teacher education, more must be known about the videos that teachers select for discussion. 


\section{THEORETICAL FRAMING}

As teachers watch video in the process of professional learning, their focus on video content is instrumental to the learning outcomes. Teacher awareness spans a threshold from subconsciously aware of what is noticed to consciously aware and able to act (Mason, 2002). Mason (2002) describes noticing as the ability to make a distinction from something or some action and its surroundings. He distinguishes between the ability to make an account-of a situation versus an account-for a situation. In cases where teachers account-for a situation, they provide a more explanatory and interpretative account whereas accounts-of practice are detailed and objective, with minimal judgment. The goal is to support teachers to move beyond evaluative judgments (e.g. Choppin, 2011; Coles, 2013) to provide descriptions and interpretations that are grounded in evidence. In the context of a video club, this would imply supporting teachers to notice video content and make interpretations about their noticing based on observations without evaluating the content of the video or those in the video.

Research on teacher noticing and video clubs has been well documented in the literature. Noticing in many studies has been defined as involving selective attention and knowledge-based reasoning (Sherin \& Dyer, 2017). This means recognizing important features of classroom interaction and drawing on one's knowledge and experiences to make sense of those interactions. This process of attending to students' thinking and interpreting students' thinking likely occurs at a similar time (e.g. Walkoe, Sherin, \& Elby, 2019), given that the focus of attention likely leads to interpretation about what is focused upon and interpretations commonly result in some features of what is observed being in the foreground (Sherin \& Dyer, 2017; Sherin \& Russ, 2015; Sherin \& Star, 2011). Similar to Mason (2002), teachers in video clubs are forced to make distinctions between their primary focus and subsequent foci as they watch video and engage in discourse with others. However, what is noticed is related to the video that is shown in the video club (Sherin \& Dyer, 2017). This raises continued questions about the videos that are used for teacher learning and videos used to develop teacher noticing. Specifically, we consider the videos teachers choose to discuss as part of a video club, recognizing that they must have noticed something in those particular videos to initiate conversation about the video.

\section{LITERATURE}

Video club designers have taken different approaches to planning video clubs. Differences exist both in the structure of video clubs and with video use that occurs as a part of the meetings. As an example, Jilk (2016) conducted a video club with practicing teachers of mathematics. The video clips used were 8-10 minutes in duration and one video was shown per meeting. The meetings typically included 25 participants and participants spoke in a go-round process of responding to prompts, which provided each teacher an opportunity to voice his or her thoughts. In contrast, Mitchell and Marin (2015) engaged four prospective teachers in a video club process to focus on what they noticed. These participants watched an unedited video approximately twenty minutes in length prior to participating in the video club meeting. Self-report data indicates the participants changed their beliefs and practices around teaching mathematics. In these two examples alone, there were stark differences in video usebetween both video length and structure of discourse. These differences could significantly impact the outcomes of the video club, and yet, the actual content and quality of the videos was not fully considered in relation to outcomes.

\section{Video Content}

The content of the videos used for video clubs and other professional learning experiences should be considered when interpreting outcomes. As Author (2017) points out, different types of video are used and edited in different ways, foregrounding some aspects of classroom practice or student thinking, while deemphasizing others. This process of highlighting and masking elements of video relates to the complexity of the video, which then can be applied to making content selections for video clubs. Differences in video influence teachers' opportunities to notice (Superfine \& Bragelman, 2018). Such differences can be thought of as those aspects of video which affect cognitive load or how much information teachers must process as they view video content. (Paas, Renkl, \& Sweller, 2003; Sweller, van Merriënboer \& Paas, 2019). In terms of cognitive load, complexity could be measured using specific load categories: intrinsic (e.g. elements inherent to the instructional material, such as the mathematics), and extraneous (e.g. aspects of video that create load but are unrelated, such as video and audio quality). Considering intrinsic and extraneous load factors in this way can guide video clip selection to enhance teacher noticing in video clubs.

Superfine and Bragelman (2018) describe in detail various categories of video complexity related to cognitive load. The material being learned comprises the intrinsic load, based on the interactivity that occurs (Superfine \& Bragelman, 2018; Sweller, 2003). Their video complexity rubric identifies intrinsic load in six dimensions. First, the depth of the enacted task, which is the nature of the mathematics being discussed and the associated challenges to understand the mathematics, contributes to complexity. Second, the clarity of children's thinking as expressed in the 
video should be considered. Third, the teacher's participation, meaning the way the teacher verbally contributes in the video is a factor. Fourth, the sequential moments of children's mathematical thinking, or the number of times instances of children's thinking occur in the video, adds to the complexity. Fifth, simultaneous moments of children's mathematical thinking, meaning the presence of multiple children discussing their thoughts at the same time further complexifies the video. Sixth, the types of children's mathematical thinking, meaning whether the thinking is expressed verbally, in writing, or in some other ways, matters. In addition to these six categories that Superfine and Bragelman (2018) consider to be intrinsic dimensions of complexity, they argue for two extraneous category considerations as well: the consideration of non-children's-mathematical-thinking moments, meaning instances that may relate to classroom management or some other action that is not the mathematics, and visual-verbal noise, meaning extra audio or visual inputs in the video that are not related to how children think about mathematics. Extraneous load dimensions are those in the design and presentation of material that require mental effort (Lee, Plass, \& Homer, 2006). Collectively, these researchers used these categories to characterize videos in a videocase curriculum; in doing so, they provided language for the mathematics education field to use to consider the complexities of video. There remain other aspects of video that could be considered for a video club context. These include elements such as the length of the video, whether there are errors in student thinking, whether the same student appears in more than one video, and even the participation structure of the students in the video, meaning whether the focus is on an individual student, a group of students, or the whole class.

\section{Video Complexity and Noticing}

Noticing, based on video, such as in the case of video clubs, is dependent on the accessibility of the content that is in the video. In other words, one cannot notice something that is not apparent. Sherin and Star (2011) noted that teachers are often faced with too many stimuli for a person to process at one point. Video can be used to reduce the inputs that teachers must filter. In fact, Kersting et al. (2016) noted that analyzing videos is not the same as analyzing an actual classroom because of the reduced complexity. Questions remain about the reduction of complexity in videos versus live classrooms and how this complexity varies across different videos. Considering variations among videos raises questions about how videos are described as a field when reporting research. Some researchers have included information in their methodology section about the videos. For example, Sherin and Russ (2015) included a table with duration, math topic, grade level, participation structure, and a summary. Similarly, van Es, Cashen, Barnhart, and Auger (2017) provided a summary of their videos and listed examples of what could be noticed from the videos. However, describing the videos in detail is not the norm in the research literature, which complicates understanding about what actually can be noticed from videos and what features (e.g. extra noise) of the video may detract from noticing. As a result, we sought to further explore and describe videos used in our video club process and connect video complexity and characteristics to the extent they affected video club meeting conversations and their duration.

\section{Quantifying Video Club Discussions}

Researchers have analyzed video club meeting data in various ways. For example, many researchers have looked at the depth of noticing of participant comments in relation to the videos watched (e.g. Sherin \& van Es, 2009; van Es \& Sherin, 2008; Walkoe, 2015). Few researchers have considered time, meaning duration of video club meeting discussion in relation to particular videos, to be an indicator of educator preference or opportunity for learning. This is in part due to the variance in structure of video clubs; many video clubs (i.e. those showing only one video; Jilk, 2016; Sherin \& van Es, 2009) would not provide opportunity for a discussion of unrestricted duration because all discussion occurred immediately following one video. Similarly, video club facilitators that show multiple videos with interspersed discussion would not be able to analyze discussion length because the facilitation focus is on moving to the next video in order to show all videos within the given time period (i.e. Luna \& Sherin, 2017). However, time of discussion can be an important indicator to better understand teacher preference for some videos over others, even though time of discussion does not provide indication of the quality of the conversation. In one of the few studies on video clubs that involves consideration of discussion time during the meeting, Borko, Virmani, Khachatryan, and Mangram (2014) analyzed video-based discussion with a focus on the percent of time each facilitator spent talking within the meeting. These researchers recorded time as a total percent of a given conversation and focused on percent of time talking as related to total number of facilitation moves. Sherin and Han (2004) also calculated percentages of discussion time from a video club. Although this research diverges from the focus of the current study, Borko et al. (2014) recognize discussion time as a variable within video club analysis. As a result of the varying structures of video clubs and the prevalence of video use in teacher education, our aim was to determine which videos from a video club teachers spend the most time discussing. Knowing how much time is spent discussing particular videos is important because it is relevant for planning future professional learning experiences and provides indication of videos that include aspects that teachers notice. We also considered it relevant to identify the complexity level and characteristics of selected and discussed videos, and focus on the 
Table 1. Participant demographic data

\begin{tabular}{ccc}
\hline Participant & Grade Taught & Years of Teaching \\
\hline Teacher 1 & Third, Fourth, Fifth (Facilitator) & 13 \\
\hline Teacher 2 & Fifth & 4 \\
\hline Teacher 3 & Fourth & 1 \\
\hline Teacher 4 & Second & 6 \\
\hline Teacher 5 & Third & 2 \\
\hline Teacher 6 & Fourth & 21 \\
\hline Facilitator 1 & Researcher/Facilitator & 17 \\
\hline
\end{tabular}

Note. All of these educators except Teacher 1 were elementary classroom teachers, meaning they taught all content areas at their specific grade. Teacher 1 taught mathematics and English Language Arts for students identified as being advanced for grades three through five. In addition, Teacher 1 supported teachers in mathematics instruction throughout the school, as directed by her principal. All of the teachers were female. Facilitator 1 was male

videos teachers pay attention to, because we consider those features that provide implications for video club designers and teacher educators more broadly.

\section{METHOD}

The following describes the video club participants, our video club process, and the data collection and analysis process.

\section{Participants}

Six teachers and one facilitator were present for each video club meeting. The teachers worked at a high-poverty (72.43\% free and reduced lunch) elementary school serving approximately 350 students in the Northwestern United States (Blind State Data, Year). Teacher demographic data is displayed in Table 1.

One of the teachers, Teacher 1 (Table 1), co-facilitated the video clubs, alongside Facilitator 1 . Facilitator 1 had extensive experience as a teacher leader and was a full-time professional development provider employed at a local university. Facilitator 1 held a Ph.D. in mathematics education and had more than a decade of experience as a regional mathematics instructional coach. The two facilitators had worked together to facilitate a year-long video club prior to the video club studied in this analysis. Both Teacher 1 and Facilitator 1 were considered participants because they were "complete member researchers" meaning "those who study settings in which they are already members or with which they become fully affiliated in the course of the research" (Denzin \& Lincoln, 2003, p. 113114).

\section{Context}

Six video club cycles were conducted over a six-month period during one academic year. In this project, a video club cycle (see Figure 1) had four parts beginning with group collaboration to plan a lesson, followed by lesson implementation (including video capture). Next, meeting preparation took place, which included video editing, followed by the video club meeting. A single cycle typically spanned three to four weeks in duration, with the most time allocated to capturing and preparing video for the video club meeting. The process is described below. 


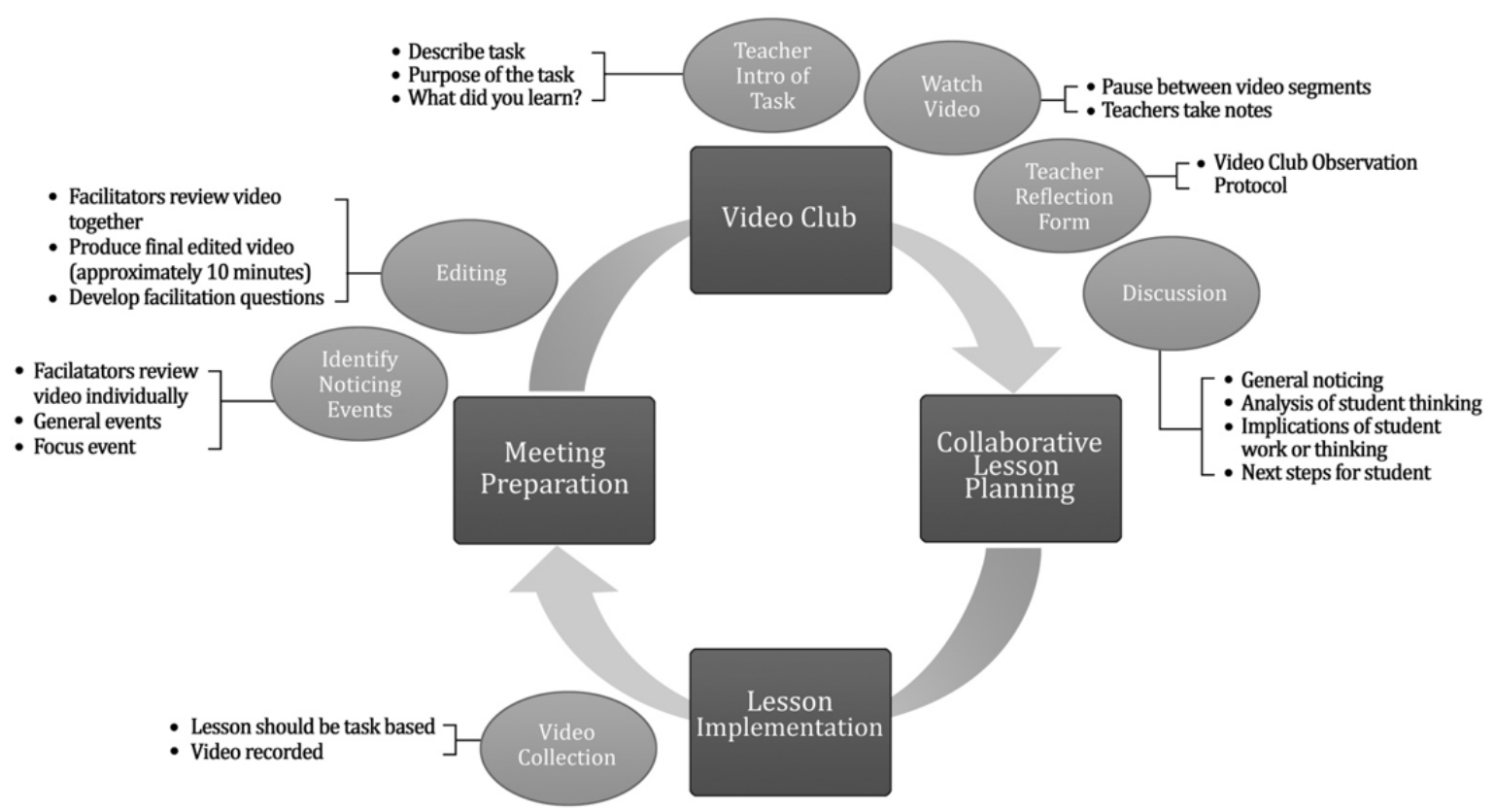

Figure 1. Video club process

Collaborative lesson planning. A discussion of lesson content for the following meeting was conducted at the conclusion of each video club meeting. A selected teacher shared a task intended to encourage student interactions with the group; watching previous video selections helped solidify the kinds of lessons that transferred well to video club settings. Once the task was presented, the video club group was able to question and make suggestions about the lesson. The feedback was informal and based on the experiences of each participant. This process was brief and took no more than 15 minutes to complete, but at times led to further discussion between teachers beyond the video club meeting.

Lesson implementation. After the collaborative planning session, the teacher who would be filmed finished planning the lesson and taught the lesson. A member of the research team filmed the lesson with professional camera and audio equipment. The videos were composed of both fixed camera positions and mobile video footage, captured when the camera operator walked around the classroom and filmed specific interactions. The camera operator collected examples of whole class discussions, teacher-student interactions, student-to-student conversations, and individual students as they worked through problems on their own. This collection of episodes presented an authentic view of the classroom. The video was compiled into one large file and transferred to the facilitators for editing.

Meeting preparation. Captured video from one lesson ranged in length from 60 minutes to 180 minutes. Each facilitator separately viewed the video in entirety, making notes as he or she watched the raw video, identifying potential noticing events within the lesson, meaning instances that foregrounded students' mathematical thinking (van Es, 2011). As an example, in one video a student explained how he would "jump" to add by twos. The moment of describing jumping by twos and showing it on his paper was considered a noticing event because it unveiled the student's mathematical thinking. The facilitators each selected multiple noticing events totaling between 15 and 20 minutes of video, from the original longer video. They met to watch all selections together, paring them to approximately ten minutes total. The resulting video clips were a negotiation between the two facilitators. Both lessons and teaching styles varied across participant teachers, so the selection process was modified accordingly. The facilitators often edited video clips to prevent viewers from seeing teacher moves, creating an opportunity for teachers viewing the video to interpret what they would have done in a given situation. These edits were intended to remove less productive teaching practices from conversation. Following the selection of video clips, one facilitator processed all of the video, selected prompts, created video overlays of student work, and assembled the files into a finished video - a compilation of the video clips - which was used during the video club meeting. The finished videos were commonly composed of four to seven edited video clips.

Video club. Video club meetings lasted between 60 and 90 minutes. Each meeting began with teachers engaging in the task featured in the meeting's video. The teacher who had taught the lesson and been filmed brought copies of the task so the other teachers could re-familiarize themselves with the content of the lesson. Approximately 15 minutes were spent discussing the mathematics of the task. All teachers were encouraged to make comments and 
Table 2. Number of videos shown for each video club

\begin{tabular}{cc}
\hline Video Club Number & Number of Video Clips Shown Before Discussion \\
\hline 1 & 5 \\
\hline 2 & 6 \\
\hline 3 & 7 \\
\hline 4 & 6 \\
\hline 5 & 5 \\
\hline 6 & 5 \\
\hline Total & 34 \\
\hline
\end{tabular}

ask questions to fully understand the mathematics or structure of the lesson before watching any videos. When appropriate, teachers were directed to anticipate possible student misconceptions that may arise.

Following the discussion of the task, each teacher and facilitator was provided a Video Club Observation Protocol. These documents were used to capture teacher noticing about the video clips and focus teachers' attention on one specific episode after viewing all videos. After watching each individual episode, the video was paused and teachers were given several minutes of silent reflection during which they wrote down critical aspects they observed and questions they had without discussion. When all participants had completed their reflection, the next video clip was shown. After all content videos were shown, teachers were given additional time to select one video that stood out to them and then asked to describe the significance of this particular video in further detail at the bottom of the Video Club Observation Protocol. We refer to the one video that each teacher selected from all of the videos as a selected video. Teachers had an additional five to seven minutes to complete their writing on this video without discussing their selection. Therefore, we categorize the video clips based on selected (meaning identified on the written form) and discussed (meaning verbally talked about during the meeting).

Although not typical of other video club structures reported in the literature (e.g. Luna \& Sherin, 2017; Sherin \& Han, 2004), the format of showing videos, writing, and then discussing was chosen because it ensured each teacher had time to reflect on what they had noticed in a particular video without the influence of others. This structure meant each member of the group could contribute to a conversation regarding any video discussed. The meeting discussion began with one teacher sharing her noticing with the group, followed by those who had written about the same video, and then by the rest of the group. For this reason, video discussion was not always sequential in nature and not every video clip shown was discussed.

\section{Data Collection}

Data included video from the teachers' classrooms (content video), video of the video club meetings (meeting video), and written data from the Video Club Observation Protocol, specifically data about the video that was selected. Prior to each video club meeting, an edited video of classroom instruction was created for review. Across the six video clubs, teachers were shown multiple video clips back-to-back that ranged from 33 seconds to 3 minutes 47 seconds. Table 2 shows the number of video clips shown for each video club.

In addition, each of the six video club meetings was recorded and later transcribed. The transcripts and meeting video provided an account of the teachers' interactions with the video clip and with each other.

\section{Data Analysis}

Content videos. The 34 video clips, termed content videos from this point forward were analyzed first. To analyze the content videos, we created a framework for analysis of video complexity, based on the work of Superfine and Bragelman (2018) with modified and added dimensions (see Appendix A for modifications and rationale). The Video Complexity Framework includes three sections: (a) qualitative aspects of the video that were recorded in narrative form and not considered with respect to complexity, yet provide context for the clips, (b) extraneous complexity factors that would affect cognitive load, and (c) intrinsic complexity factors that would affect cognitive load. Figure 2 shows this framework, with assigned values for complexity. The maximum score for extraneous complexity was 4 and for intrinsic complexity was 6, for a total maximum complexity score of 10 . With this framework, we recognize that all complexity characteristic categories were treated seemingly equal; although there could be differences in the amount that a particular category contributed to complexity, we did not believe that assigning an arbitrary value to each characteristic would accomplish more than treating them equally. 


\begin{tabular}{|c|c|c|c|}
\hline $\begin{array}{l}\text { Complexity } \\
\text { Characteristic }\end{array}$ & Description & Codes & $\begin{array}{l}\text { Complexity } \\
\text { Value }\end{array}$ \\
\hline \multicolumn{4}{|c|}{ Qualitative Aspects } \\
\hline $\begin{array}{l}\text { Summary } \\
\text { Description }\end{array}$ & $\begin{array}{l}\text { Ten word or less description of } \\
\text { the video }\end{array}$ & Written narrative & $\begin{array}{c}\text { No complexity } \\
\text { value }\end{array}$ \\
\hline $\begin{array}{l}\text { Participation } \\
\text { Structure }\end{array}$ & $\begin{array}{l}\text { Focus of arrangement of } \\
\text { students during the lesson } \\
\text { (could have more than one } \\
\text { foci) }\end{array}$ & $\begin{array}{l}\text { Whole-class } \\
\text { Pairs } \\
\text { Individual } \\
\text { Combination of Elements } \\
\text { Student Work Only }\end{array}$ & $\begin{array}{l}\text { No complexity } \\
\text { value }\end{array}$ \\
\hline & & $\begin{array}{l}\text { Teacher } \\
\text { Student Work }\end{array}$ & \\
\hline Enhanced Video & $\begin{array}{l}\text { Graphical recreation or } \\
\text { enlarged image of student } \\
\text { work }\end{array}$ & $\begin{array}{l}\text { Enhanced } \\
\text { Not Enhanced }\end{array}$ & $\begin{array}{l}\text { No complexity } \\
\text { value }\end{array}$ \\
\hline Student Presence & $\begin{array}{l}\text { Extent to which the same child } \\
\text { appears in multiple videos }\end{array}$ & $\begin{array}{l}\text { Yes (if so, list video numbers) } \\
\text { No }\end{array}$ & $\begin{array}{c}\text { No complexity } \\
\text { value }\end{array}$ \\
\hline \multicolumn{4}{|c|}{ Extraneous Complexity Factors } \\
\hline Audio Clarity & $\begin{array}{l}\text { Clarity of the auditory aspects } \\
\text { of the video }\end{array}$ & $\begin{array}{l}\text { No Issues } \\
\text { Minor Issues } \\
\text { Major Issues }\end{array}$ & $\begin{array}{l}(0) \\
(0.5) \\
(1)\end{array}$ \\
\hline Video Clarity & $\begin{array}{l}\text { Clarity of the visual aspects of } \\
\text { the video (i.e. blurry, clear) }\end{array}$ & $\begin{array}{l}\text { No Issues } \\
\text { Minor Issues } \\
\text { Major Issues }\end{array}$ & $\begin{array}{l}(0) \\
(0.5) \\
(1)\end{array}$ \\
\hline $\begin{array}{l}\text { Non-Children's } \\
\text { Mathematical } \\
\text { Thinking Moments }\end{array}$ & $\begin{array}{l}\text { Moments that can be attended } \\
\text { to that are not children's } \\
\text { mathematical thinking }\end{array}$ & $\begin{array}{l}\text { None } \\
\text { One moment of non-children's mathematical thinking } \\
\text { Several moment of non-children's mathematical thinking }\end{array}$ & $\begin{array}{l}(0) \\
(0.5) \\
(1)\end{array}$ \\
\hline Visual-Verbal Noise & $\begin{array}{l}\text { Extraneous Information in the } \\
\text { videos }\end{array}$ & $\begin{array}{l}\text { No extraneous load } \\
\text { One channel has extraneous load-visual or audio } \\
\text { Both channels have extraneous load- visual and audio }\end{array}$ & $\begin{array}{l}(0) \\
(0.5) \\
(1)\end{array}$ \\
\hline \multicolumn{4}{|c|}{ Intrinsic Complexity Factors } \\
\hline $\begin{array}{l}\text { Depth of Enacted } \\
\text { Task }\end{array}$ & $\begin{array}{l}\text { The number of foci being } \\
\text { discussed/argued, number of } \\
\text { strategies presented/discussed, } \\
\text { use of multiple representations }\end{array}$ & $\begin{array}{l}\text { One topic or strategy discussed; multiple representations } \\
\text { not present } \\
\text { Several strategies being discussed; multiple representations } \\
\text { used or strategies present }\end{array}$ & (0) \\
\hline $\begin{array}{l}\text { Errors of Student } \\
\text { Thinking }\end{array}$ & $\begin{array}{l}\text { Presence of student } \\
\text { misconception or error }\end{array}$ & $\begin{array}{l}\text { No error in thinking } \\
\text { Error present in thinking }\end{array}$ & $\begin{array}{l}(0) \\
(1) \\
\end{array}$ \\
\hline $\begin{array}{l}\text { Clarity of Child } \\
\text { Thinking }\end{array}$ & $\begin{array}{l}\text { Feasibility to understand the } \\
\text { child's thinking in the video }\end{array}$ & $\begin{array}{l}\text { Child's thinking is transparent, single interpretation is } \\
\text { obvious } \\
\text { Child's thinking is not transparent }\end{array}$ & (1) \\
\hline $\begin{array}{l}\text { Teacher } \\
\text { Participation }\end{array}$ & $\begin{array}{l}\text { Extent to which teacher } \\
\text { questions prime attention } \\
\text { toward children's mathematical } \\
\text { thinking }\end{array}$ & $\begin{array}{l}\text { No questions asked } \\
\text { Teacher asks questions related to children's mathematical } \\
\text { thinking } \\
\text { Teacher asks questions related to issues that are not } \\
\text { children's mathematical thinking } \\
\text { Teacher asks questions both about children's mathematical } \\
\text { thinking and about topics that are not children's' } \\
\text { mathematical thinking }\end{array}$ & $\begin{array}{l}(0) \\
(0.5) \\
(0.5)\end{array}$ \\
\hline $\begin{array}{l}\text { Moments of } \\
\text { Children's } \\
\text { Mathematical } \\
\text { Thinking }\end{array}$ & $\begin{array}{l}\text { Number of times and number } \\
\text { of children discussion children's } \\
\text { mathematical thinking }\end{array}$ & $\begin{array}{l}\text { Children take turns expressing their mathematical thinking } \\
\text { with one child talking at a time } \\
\text { Multiple children discuss children's mathematical thinking } \\
\text { simultaneously }\end{array}$ & (0) \\
\hline $\begin{array}{l}\text { Types of Children's } \\
\text { Mathematical } \\
\text { Thinking }\end{array}$ & $\begin{array}{l}\text { Extent to which children's } \\
\text { mathematical thinking is } \\
\text { expressed verbally or in writing }\end{array}$ & $\begin{array}{l}\text { Audio or visual } \\
\text { Audio and visual }\end{array}$ & $\begin{array}{l}(0) \\
(1)\end{array}$ \\
\hline
\end{tabular}

Figure 2. Video Complexity Framework, adapted from Superfine and Bragelman (2018)

We recognize that not all complexity characteristics (Figure 2, left column) are equal, for example, teacher participation may affect complexity differently than clarity of student thinking; however, for the purposes of our 
analysis, this process allowed us to discuss relative complexity to compare videos. In other words, we applied the same framework to each video, which gave us a complexity score for each content video that could then be considered in relation to discussion length. The following describes the coding process.

To establish reliability in coding, three researchers each independently coded three content videos for each category in the Video Complexity Framework. The three researchers met to compare codes, discuss definitions, and then reconciled differences. The same three researchers then each coded the remaining 31 content videos, again for each of the categories in the Video Complexity Framework. The three researchers met and reconciled any codes. In instances of disagreement, the content videos were re-watched and a group consensus was reached on the codes. This analysis process resulted in a complexity score for each of the 34 content videos.

We also analyzed all content videos that participants had specifically discussed $(n=22)$ for characteristics of the video content. Two researchers independently viewed all of the discussed content videos and open coded for themes (Corbin \& Strauss, 2007). The two researchers then met to reconcile differences and rewatched the videos to arrive at a codebook. Codes included: student flexibility (i.e. whether or not the student was willing to change their thinking), student errors/misconceptions (i.e. miscalculation or not understanding), scaffolding (i.e. teacher support), questioning (i.e. whether the teacher asked the students questions directly), and connections to pedagogy (i.e. the video included facilitator-inserted prompts to push teachers to think about pedagogical aspects). The two researchers then recoded all content videos and reconciled differences in codes.

Meeting videos. Following the analysis of the content videos for complexity, the video club meeting videos were analyzed to determine the amount of time the video club participants spent discussing each content video. This process was completed by two researchers who compared notes about discussion time on each content video. This process of determining length of discussion during the meeting on a particular content video was challenging at times because the teachers did not talk about the videos in the order they were viewed and conversation often bounced from one video to the next. The two researchers re-watched the meeting videos until they arrived at a consensus for the discussion time for each content video during the video club meeting. This analysis process provided a discussion length time for each of the 34 content videos (12 were never discussed). We then analyzed the meeting video data for descriptive statistics and conducted statistical analysis to determine correlations in the data.

Video Club Observation Protocol data. Finally, we focused on the Video Club Observation Protocol. Two researchers each read every protocol in entirety to determine the selected content video each participant wrote about at length. Recall that the protocol asked participants to select and write about one content video from the several they had viewed that day. The two researchers met and agreed on all selected videos. We then created a table listing the selected content video for each participant and compared that to complexity.

\section{RESULTS}

We hoped to better understand the impact of video complexity characteristics on teacher discussion, including video selection and length of discussion about individual videos. We expected to find associations between video complexity and the length of time participants spent discussing content videos during the video club meetings. As a result, we explored whether video complexity had an effect on video selection-meaning the content video a teacher noticed, or wrote about as a primary focus for discussion. Next we examined the relationship between video complexity and length of teacher discussion, before investigating connections between video content and length of teacher discussion. We begin with a review of descriptive statistics for the videos shown during the meetings. Table 3 provides an overview of the complexity of the 34 content videos that were shown during the video club meetings, with the number and percentage of videos with each characteristic.

As evidenced in Table 3, most videos included the teacher (79\%), showed some type of student work (79\%), and were free of clarity issues - audio (71\%), video (85\%). A majority of the videos included student presence (71\%), meaning the same child in one content video was in another content video that was shown for that same video club meeting. The content videos were almost evenly divided on the depth of the enacted task, meaning one or more than one strategy or representation was used. Similar characteristics were found for errors in student thinking, with about half of the content videos including some type of error. Students' thinking was clear in about half of the videos. Of interest, the teacher asked questions related to children's mathematical thinking in $68 \%$ of the videos and most videos (91\%) included children's mathematical thinking expressed both verbally and visually. Half of the videos included both visual and verbal distractors, such as someone walking in the background or students talking in the background. We provide these descriptive statistics to demonstrate the content of the edited videos the facilitators developed. These descriptions also provide context for considering complexity and themes among the videos that were discussed. 
Table 3. Coding Frequencies for Complexity Characteristics of Content Videos

\begin{tabular}{|c|c|c|c|}
\hline $\begin{array}{l}\text { Complexity } \\
\text { Characteristic }\end{array}$ & Codes & $\begin{array}{l}\text { Number } \\
\text { of Videos }\end{array}$ & $\begin{array}{c}\text { Percentage } \\
\text { of Videos }\end{array}$ \\
\hline \multicolumn{4}{|c|}{ Qualitative Aspects } \\
\hline \multirow[t]{8}{*}{ Participation Structure } & Whole-class & 2 & $6 \%$ \\
\hline & Groups & 4 & $12 \%$ \\
\hline & Pairs & 13 & $38 \%$ \\
\hline & Individual & 7 & $21 \%$ \\
\hline & Combination of Elements & 6 & $18 \%$ \\
\hline & Student Work Only & 2 & $6 \%$ \\
\hline & Teacher & 27 & $79 \%$ \\
\hline & Student Work & 27 & $79 \%$ \\
\hline \multirow[t]{2}{*}{ Enhanced Video } & Enhanced & 7 & $21 \%$ \\
\hline & Not Enhanced & 27 & $79 \%$ \\
\hline \multirow[t]{2}{*}{ Student Presence } & Yes & 24 & $71 \%$ \\
\hline & No & 10 & $29 \%$ \\
\hline \multicolumn{4}{|c|}{ Extraneous Complexity Factors } \\
\hline \multirow[t]{3}{*}{ Audio Claritya } & No Issues & 24 & $71 \%$ \\
\hline & Minor Issues & 6 & $18 \%$ \\
\hline & Major Issues & 2 & $6 \%$ \\
\hline \multirow[t]{3}{*}{ Video Clarity } & No Issues & 29 & $85 \%$ \\
\hline & Minor Issues & 4 & $12 \%$ \\
\hline & Major Issues & 1 & $3 \%$ \\
\hline Non-Children's & None & 27 & $79 \%$ \\
\hline Mathematical Thinking & One moment of non-children's mathematical thinking & 5 & $15 \%$ \\
\hline Moments & Several moment of non-children's mathematical thinking & 2 & $6 \%$ \\
\hline \multirow[t]{3}{*}{ Visual-Verbal Noise } & No extraneous load & 4 & $12 \%$ \\
\hline & One channel have extraneous load-visual or audio & 13 & $38 \%$ \\
\hline & Both channels have extraneous load- visual and audio & 17 & $50 \%$ \\
\hline \multicolumn{4}{|c|}{ Intrinsic Complexity Factors } \\
\hline \multirow[t]{2}{*}{ Depth of Enacted Task ${ }^{b}$} & One topic or strategy discussed; multiple representations no present & 17 & $50 \%$ \\
\hline & $\begin{array}{l}\text { Several strategies being discussed; multiple representations used or } \\
\text { strategies present }\end{array}$ & 16 & $47 \%$ \\
\hline \multirow[t]{2}{*}{ Errors of Student Thinking } & No error in thinking & 14 & $41 \%$ \\
\hline & Error present in thinking & 20 & $59 \%$ \\
\hline \multirow[t]{2}{*}{ Clarity of Child Thinking ${ }^{\mathrm{b}}$} & Child's thinking is transparent, single interpretation is obvious & 16 & $47 \%$ \\
\hline & Child's thinking is not transparent & 17 & $50 \%$ \\
\hline \multirow[t]{5}{*}{ Teacher Participation ${ }^{\mathrm{b}}$} & No questions asked & 7 & $21 \%$ \\
\hline & Teacher asks questions related to children's mathematical thinking & 23 & $68 \%$ \\
\hline & Teacher asks questions related to issues that are not children's & 0 & $0 \%$ \\
\hline & Teacher asks questions both about children's mathematical thinking and & 0 & \\
\hline & about topics that are not children's' mathematical thinking & 4 & $12 \%$ \\
\hline \multirow[t]{2}{*}{$\begin{array}{l}\text { Moments of Children's } \\
\text { Mathematical Thinking }\end{array}$} & $\begin{array}{l}\text { Children take turns expressing their mathematical thinking with one child } \\
\text { talking at a time }\end{array}$ & 25 & $74 \%$ \\
\hline & Multiple children discuss children's mathematical thinking simultaneously & 8 & $24 \%$ \\
\hline Types of Children's & Verbal or visual & 3 & $9 \%$ \\
\hline Mathematical Thinking & Verbal and visual & 31 & $91 \%$ \\
\hline
\end{tabular}

aTwo videos purposely had no audio.

${ }^{b}$ One video showed only a still image of student work.

\section{Selected Videos}

We found a relationship between video complexity and selected videos, meaning those in which participants noticed a particular aspect or happening, and then selected that content video and wrote about what they noticed on the Video Club Observation Protocol. Ten was the maximum complexity score possible given the framework (Figure 2); however, of all 34 content videos shown, 8 was the highest complexity score of any video. Table 4 shows complexity scores for each selected video per teacher, per meeting. 
Table 4. Complexity of Content Video Selected by Participant as Recorded on the Video Observation Protocol per Video Club Meeting

\begin{tabular}{|c|c|c|c|c|c|c|}
\hline \multirow[t]{2}{*}{ Participant } & \multicolumn{6}{|c|}{ Clip Selected } \\
\hline & Video Club 1 & Video Club 2 & Video Club 3 & Video Club 4 & Video Club 5 & Video Club 6 \\
\hline Teacher 1 & 7 & 4 & 2 & 3.5 & 5.5 & 3.5 \\
\hline Teacher 2 & & 5 & 5 & 2 & & 3 \\
\hline Teacher 3 & & 5.5 & 5 & 2 & & 7 \\
\hline Teacher 4 & & 4 & 5 & 3.5 & 1.5 & 3.5 \\
\hline Teacher 5 & & 5 & 5 & 5 & 1.5 & 3 \\
\hline Teacher 6 & & & 5 & 6 & & 3 \\
\hline Facilitator 1 & 7 & 5 & 5 & 6.5 & & 1.5 \\
\hline Average Complexity Score & & 4.75 & 4.57 & 4.07 & 2.83 & 3.5 \\
\hline Maximum Complexity of Shown Video & 7 & 5.5 & 8 & 6.5 & 5.5 & 7 \\
\hline $\begin{array}{l}\text { Difference between average complexity } \\
\text { and maximum complexity }\end{array}$ & & 0.75 & 3.43 & 2.43 & 2.67 & 3.5 \\
\hline
\end{tabular}

Note. Missing data indicates either the participant was not present at the meeting or did not make a selection on the Video Club Observation Protocol.

Table 5. Means, Standard Deviations, and Ranges of Complexity of Content Videos as a Function of Discussion Length

\begin{tabular}{ccccccc}
\hline \multirow{2}{*}{ Discussion Length (in Minutes) } & \multirow{2}{*}{} & \multicolumn{4}{c}{ Complexity Score } \\
\cline { 3 - 6 } & & $\boldsymbol{M}$ & SD & Minimum & Maximum \\
\hline 1 to 5 & 7 & 4.21 & 1.80 & 1.50 & 7.00 \\
\hline 6 to 10 & 9 & 4.50 & 1.35 & 1.50 & 6.00 \\
\hline 11 to 15 & 5 & 4.10 & 2.46 & 2.00 & 7.00 \\
\hline 16 to 20 & $--^{a}$ & -- & -- & -- & -- \\
\hline 21 to 25 & 1 & 3.50 & NaN & 3.50 & 3.50 \\
\hline Not discussed & 12 & 4.13 & 1.75 & 1.50 & 8.00 \\
\hline
\end{tabular}

No discussions fell within the 16 to 20 minute range.

Analysis of the relationship between the complexity score and whether the participants selected a video is not significant, but the directionality of the finding is interesting. The correlation of -0.3 suggests that there is an inverse relationship between video complexity and whether participants selected a particular content video. In other words, as the complexity of a video increased, participants were less likely to choose that particular video as a video to write about on the observation form. Therefore, the video that included an aspect that was the most relevant to the greatest number of participants (concluded based on what video they wrote about, i.e. Table 4), suggests they noticed aspects from less complex videos. Additionally, over time, the average complexity of the videos participants selected declined from 4.75 (Video Club 2) to 3.5 (Video Club 6), suggesting that over time participants noticed aspects from videos that were less complex. When compared with the maximum complexity score of any video shown in a particular video club, the difference between possible video complexity and average complexity increased. This suggests that at the later video club meetings, participants had the opportunity to notice complex videos, but did not select videos with higher complexity values.

Further correlational analysis between selected videos and the participation structure of the students in the video shows a positive correlation of $0.03 p<.053$. Although not statistically significant, this finding indicates that participants commonly selected videos (as indicated by their Video Club Observation Protocol) that included whole class participant structures. Recognizing these findings about the selected clips, we sought to know more about the characteristics of the videos that were actually discussed in the meetings and which clips were discussed at greatest length.

\section{Discussion Length versus Videos Discussed}

Of the 34 content videos shown during the video club, 22 were discussed by participants during the video club meetings. Correlational analysis was used to examine the relationship between video complexity and length of teacher discussion for these 22 videos. Results indicated no significant relationship between the variables. Table 5 shows the discussion length during the video club, number of videos for each discussion length category, the mean complexity score and the standard deviation, it also includes the complexity information for those videos not selected during video club. The maximum complexity score possible for a video was 10 .

As evidenced in the table, most content videos were discussed between one and 15 minutes, with no videos discussed for 16 to 23 and only one video discussed for more than 21 minutes. The mean for complexity scores was similar based on discussion length, with greater variability (higher standard deviation) for videos that were 


\section{Content Video Clip Primary Participant Structure}

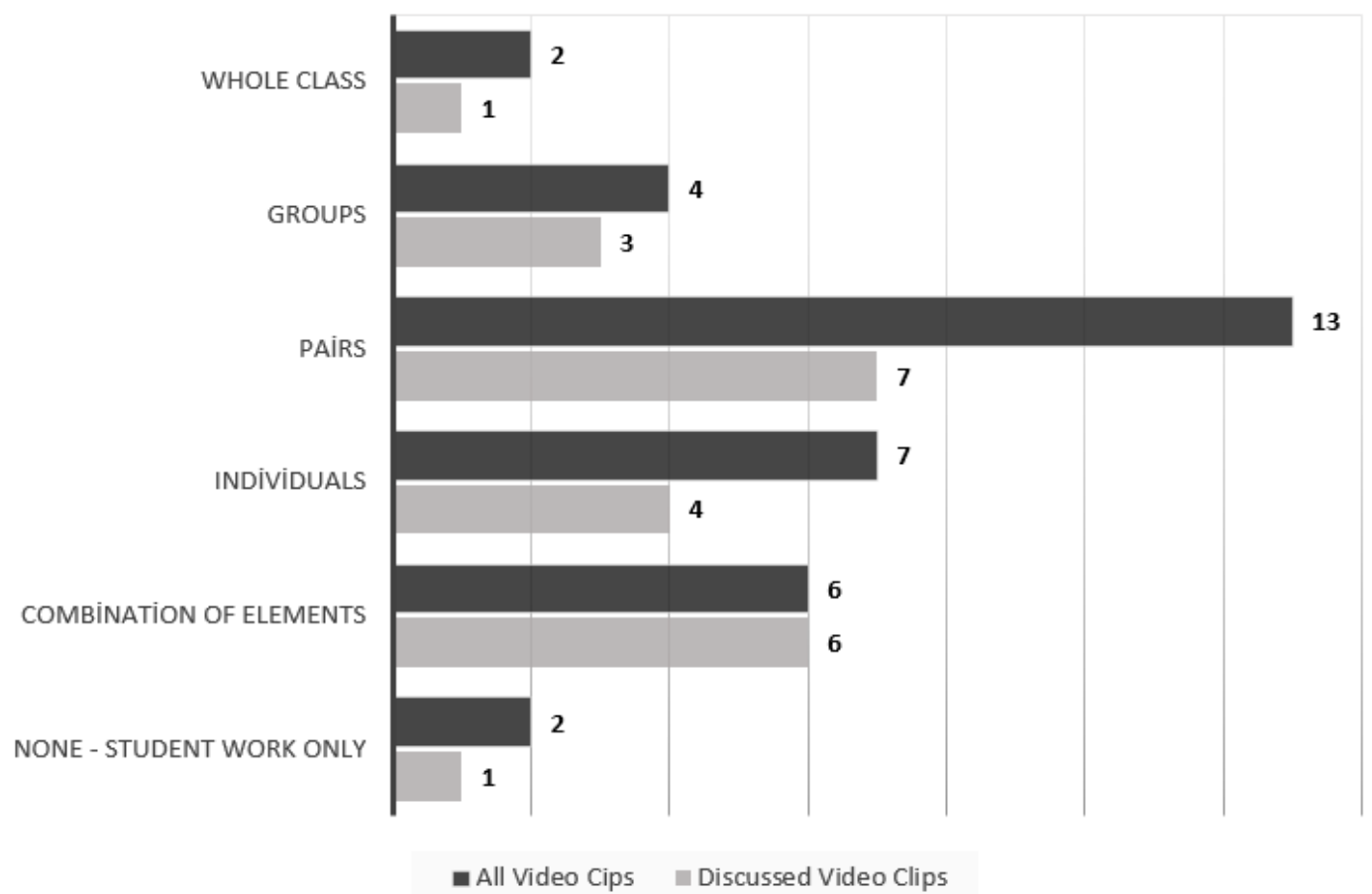

Figure 3. Counts of primary participant structures: whole class, groups, pairs, individuals, a combination of those elements, or student work only

discussed 11 to 15 minutes (range of 5 on complexity scale for these videos). The video that had the highest complexity score (8) was not discussed at all.

Participation structure of discussed videos. We compared the participation structure of the students in content videos that were discussed with the participation structure of the students in all content videos. Figure 3 shows the participation structure for all videos versus those discussed.

Of interest, all content videos that had a variety of student participation structures (e.g. groups and pairs, individuals and whole class, etc.) were discussed (six of six). In videos that only showed a pair of students, approximately half of these were discussed (seven of 13). The fact that all videos including a combination of participation structures were discussed suggests that videos with this type of complexity may be favored for discussions.

\section{Content Themes within Discussed Videos}

In addition to the quantitative analysis, we sought to understand more about the substance of the videos that were discussed to better understand the content in those videos that may have prompted discourse. Qualitative analysis of the videos discussed revealed three main themes in the content videos; two of these aligned with elements that had been coded as part of the complexity scale. First, teacher scaffolding and questioning occurred in a majority of the discussed videos (68\%). As an example, in the following transcript from a video, the teacher scaffolded a student's thinking and asked probing questions [indicated with bold], based on the following mathematical problem: A company has 187 orange juice cartons. They want to put them in boxes. If nine cartons can fit into one box, how many boxes will they need?

Teacher: A company has 187 juice cartons. Got it? They want to put them in boxes. If nine cartons can fit in one box, how many boxes will they need? Now, can you explain this to me? 'Cuz I see this, and I see this, which almost looks like two different answers.

Student: Well, the reason I did 21 boxes is because you can't just have seven - if they want to put all of their, um, orange juice cartons -

Teacher: Take me back further. Take me back further.

Student: Okay. I was dividing using long division.

Teacher: Okay.

Student: And I did 187. I knew that nine plus nine is 18; so, 90 plus 90 was 180. 
Teacher: Perfect.

Student: I did 10 to 20, which got me 180 .

Teacher: Great. Way to use your numbers, okay.

Student: It was seven left over. And you can't take nine away from seven, 'cuz there isn't any.

Teacher: Got it.

Student: So, I put 20, remainder seven-

Teacher: Which is what?

Student: Um-

Teacher: In your story problem, what does that represent?

Student: It represents 21 boxes. 20 is full boxes -

Teacher: Oh! -

Student: And then the seven is a semi-full box.

In this example, the teacher pushed the student to think with support and also asked questions. This type of teacher involvement, scaffolding and asking questions, occurred in most of the videos.

Another theme from both the complexity analysis and later the qualitative analysis that was commonly evident, was the inclusion of some type of student misconception in the video. Over half (59\%) of the videos that were discussed contained some type of misconception on the part of the student. The following is an example of a misconception [indicated with bold] from a video when the student was asked to write a word problem for 187 divided by 9 .

Teacher: Yeah. What do you have?

Student: There are nine families and there are 187 cookies -

Teacher: Okay, I'm visualizing. So, there's nine families, and there's 187 cookies - okay, got it.

Student: How many cookies will each family get?

Teacher: Hmmm. Okay. How did you work it out here?

Student: I've done nine divided by 187.

Teacher: Say that again.

Student: I've done nine by divided by 187.

Teacher: Okay, do you hear how you're saying that? Visualize nine divided by 187.

Student: I was sayin', how many can go on each pan, though?

In this example, the student confused 187 divided by 9 with 9 divided by 187, possibly indicating a lack of understanding that division is not commutative. The context the student provides in the created problem makes sense (i.e. dividing 187 among 9 families), but when working out the problem, the student said the problem was 9 divided by 187. Misconceptions, such as this example, were evident in nearly half of the content videos.

Flexibility in student thinking was the third theme evident base on the qualitative coding and had not been a consideration during the complexity coding. Many content videos included students that were absolute in their thinking; meaning in the video, they were certain their approach or answer was correct, even when it was incorrect and the teacher pushed the student to reconsider. The following is an example of two students interacting as they lacked flexibility in their thinking. Figure 4 shows the written student work, as two students talk to determine the perimeter of the shaded region.

In the example based on Figure 4, Student 2 led the conversation and counted inaccurately; Student 1 went along with what Student 2 said. Both students counted the squares as six during the clip, with Student 1 counting as if to confirm Student 2's thinking. [Bold indicates absolute thinking].

Student 1: What? So seven plus one, two, three, four, five, six.

Teacher: But that's a square.

Student 1: This is supposed to be seven...can this be one?

Student 2: Does that count as a square? [Student questions whether the one and a half grid square on the right side can be counted as one which will confirm the lines she already drew.]

Student 1: I'm pretty sure this would be a one, right here. [Student points to one and a half squares on the grid, considering one and a half to be one.]

Student 2: One, two, three, four, five, six - [Student confirms his picture, counting to six by counting the right one and a half grid squares as one and seemingly ignoring the half on the left side.] 


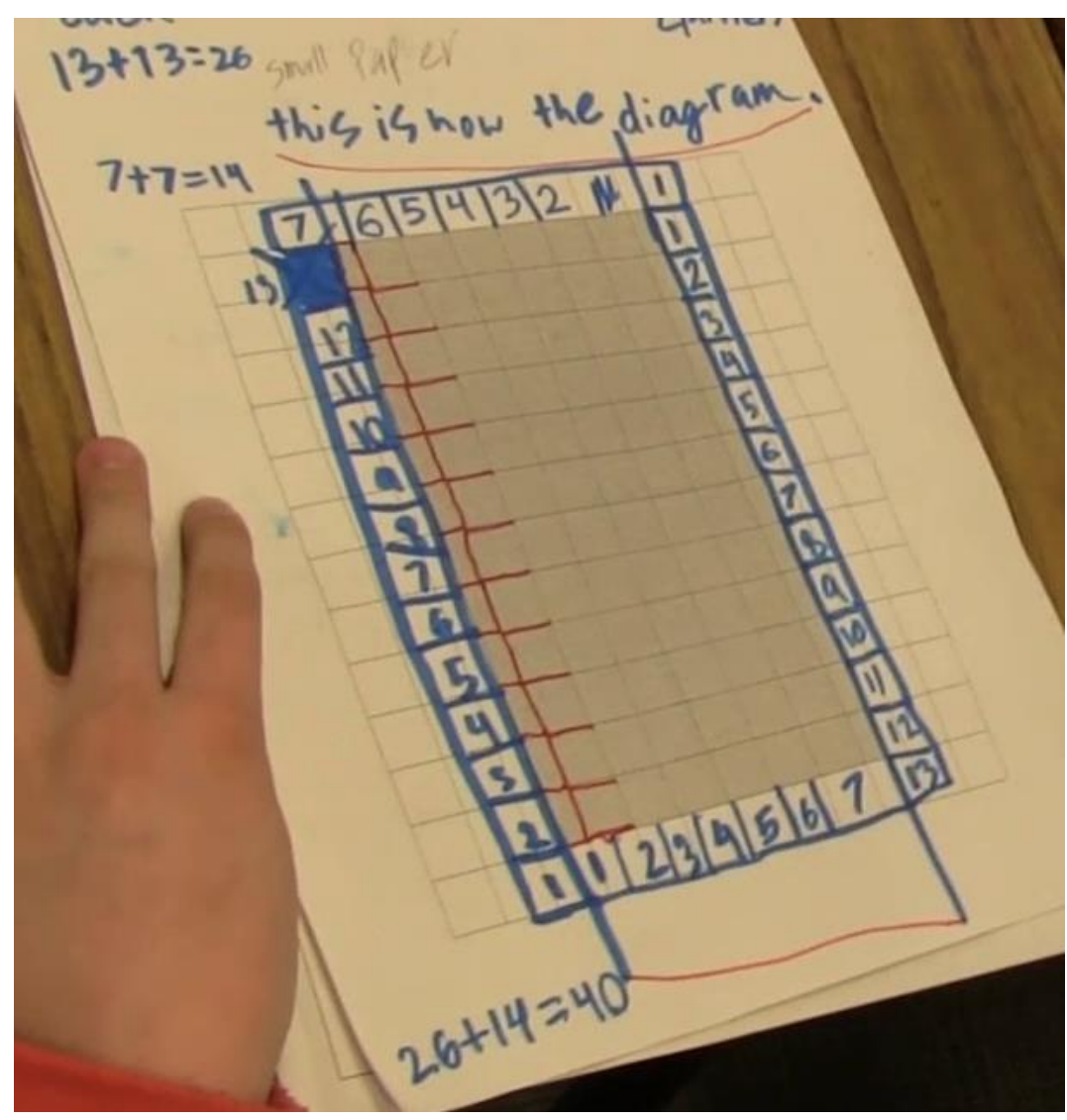

Figure 4. Image of student work to show counting to find perimeter

Student 1: That's kind of a half.

Student 2: One, two, three, four, five, six. [Student reconfirms his count]

Student 1: Three, four, five, six. [Student 1 mirrors Student 2's count, now]

Teacher: Okay. So what went wrong at the bottom versus the top?

In this example, the students had six whole squares with two one-half squares at both the top and bottom of the rectangle; they drew their own lines to make it six. Then, when asked to count out the squares, the students used their original lines instead of the printed ones to show there were six squares. The students had a difficult time using the other lines. This example, and the previous two examples, represent themes from discussed videos as they included teacher scaffolding, student misconceptions, and students who were having a difficult time thinking beyond their original assertions.

\section{DISCUSSION}

The intent of this study was to describe how the complexity of a video shown during a video club related to the amount of time participants spent discussing the given video and to describe characteristics of videos selected and discussed during video club meetings. Findings indicate that participants discussed videos that varied in complexity and focus, meaning, statistically, there were not clear identifiers to separate the videos that were discussed from those that were not discussed or to say that videos with certain characteristics were discussed in a longer duration than other videos. However, findings indicate that teachers more often discussed videos with lower complexity levels. Further, the findings provide an overview of characteristics of videos that were discussed, provide data on the duration of discussion of certain videos, and highlight qualitative characteristics of the videos that were selected and talked about during the video club meetings.

Our findings build on those of Superfine and Bragelman (2018) who argued that additional consideration should be given to the characteristics of videos that are used to support teacher learning. In their study, they compared video complexity with teacher noticing and highlighted the differences between intrinsic and extraneous load properties, in accordance with cognitive load theory (e.g. Sweller, 2003). We followed a similar trend and found that videos with the highest levels of complexity were not selected. This may suggest that teachers may have 
a more difficult time noticing salient aspect of classroom practice in videos that require high cognitive load for understanding. Our analysis also provided a glimpse into slightly different aspects of cognitive load of video (see Appendix A) than did the work of Superfine and Bragelman (2018). They coded videos for complexity using a binary scale, which varies from the process in the current paper, in which we used intervals ranging from 0 to 1 to account for additional intrinsic and extraneous properties of the videos. It is possible that the findings of the present study may be different if we had used a binary coding process, which could have provided opportunity for additional statistical analysis. The findings from the present study provide contributions to the field of teacher education, both theoretically and practically. The following sections discuss these contributions.

\section{Theoretical Contributions}

Results indicate teachers discussed particular content videos during video club meetings and the duration of these conversations varied. This raises questions about the content of the videos that were discussed, meaning elements that were noticed (Mason, 2002). As Mason (2002; 2011) noted, for a teacher to discuss a certain video, that teacher must first notice something salient in the video that is distinguished from other features and then mark, or explicitly make notice of that moment to him or herself. Theoretically, findings from this work indicate that teachers were able to notice, mark, and make mention of aspects within the videos that they noticed; this finding is not new, as numerous researchers have studied video clubs and the discussion of videos (e.g. Luna \& Sherin, 2017; Sherin \& Han, 2004; van Es \& Sherin, 2008). However, the findings from the present study provide insight about the characteristics of the videos that were discussed. Additionally, the use of the Video Club Observation Protocol forced the teachers to notice, mark, and then record what had seemed notable from the video-resulting in their selected videos. This process engendered a heightened form of awareness and could have influenced what they ultimately discussed (Mason, 2002). Interestingly, the complexity of the videos the teachers wrote about declined over the course of the video club process, indicating they noticed aspects from less complex videos and recorded notes about those videos as time passed. Notably, teachers discussed videos depicting more than one participation structure, suggesting that videos that include variety in participation structure-such as those that shift from a focus on a single student to a focus on a whole group - may engender conversation. Additionally, videos that were discussed often included teacher scaffolding and questioning, student misconceptions, or a student who was seemingly inflexible in their thinking. Further research could examine the relationship between teacher noticing and videos that specifically contain or do not contain these features to better understand the relationship between noticing and videos in teacher education.

\section{Practical Contributions}

Practically, the contributions of this work provide the teacher education field (beyond mathematics education) with a framework to consider and classify the complexity of videos used. The Video Complexity Framework (Figure 2) is an adaptation of Superfine and Bragelman's (2018) framework, with expanded categories. This framework provides teacher educators with a lens to examine the types of videos they show to teachers and teacher candidates for learning purposes. For example, teacher educators should be aware of the possible complexities of videos (i.e. Figure 2) when showing video for professional development purposes or for teacher education purposes, such as in a methods course. As an example, the teacher educator could view the video with questions about whether there were errors in student thinking in the video, whether the teacher participated, or whether children are expressing their thinking verbally or visually in the video, among others. In other words, because video is used regularly in teacher education (e.g. Brophy, 2003; Christ, Arya, \& Chiu, 2017; Goldman, Pea, Barron, \& Derry, 2014), those selecting the video should be intentional with the contents of the video and aware of the differences in complexity among various videos. Applying a framework, such as the Video Complexity Framework (Figure 2) is a practical consideration for teacher educators to formulate ideas about the videos they use. We consider the creation of this framework to be a contribution to the field.

Additionally, findings provide some indication about whether teachers will choose to discuss particular videos in a video club context. Although modest, a slight correlation suggested an inverse relationship between video complexity and whether teachers selected the video, meaning teachers were less likely to choose to discuss a video with greater complexity. These findings are similar to Sherin et al. (2009) who found that videos that were rated high for depth did not necessarily lead to productive discussions. Although, we did not evaluate the discussion quality. For teacher educators, this finding suggests that teachers may avoid discussing videos that seem more complex than other videos; in other words, and seemingly natural, in the video club, teachers likely talked about the videos they could more easily process. Considering cognitive load theory, deciphering intrinsic load aspects of video can be a daunting cognitive process (Superfine \& Bragelman, 2018; Sweller, 2003), so supporting teachers and scaffolding them to engage in discourse about complex videos may be necessary. Practically, teacher educators should be aware that teachers may not always choose to discuss complex videos. In these cases, teacher educators 
should be prepared with facilitation moves (e.g. van Es, Tunney, Goldsmith, \& Seago, 2014) to help teachers begin to talk about aspects of the videos that may add to the complexity.

Clip selection is another factor in this study that should be considered. Each video club meeting included several video clips that had been edited from the original video footage and were used for the meetings. As evidenced in Table 4, the complexity of the clips shown varied (i.e. Table 4 reports highest clip complexity for each meeting). Kang and van Es (2018) argue that clip selection should involve consideration of the appropriate grain size of a video, as well as consideration for the quality of the video clip. In conjunction with the work of Superfine and Bragelman (2018), this work attempts to illuminate characteristics of videos clips that were selected for the video club meetings. Ideally, professional development providers will consider these attributes of clips when they select clips to use, rather than considering complexity after use.

Additionally, duration of time for particular discussions may be something to further consider, as Sherin and Han (2004) considered time duration of discussions as related to the topic of discussion. As evidenced in the data, teachers talked for one to twenty-five minutes about one given content video, with most conversations lasting between six and ten minutes, but we did not equate length of time with any type of quality indicator related to the discussion. Practically though, teacher educators should be aware of these times as they may relate to professional learning opportunities. Based on the video club structure we used, the participants could talk for any duration of time. Because of the format of other video clubs (e.g. Jilk, 2016), this type of time duration analysis had not been possible previously. We contend that knowing the natural duration of conversation for a given video clip (and knowing relative complexity) provides insight to those using video in teacher education.

\section{Considerations for the Field}

The existing literature on video complexity is limited. Superfine and Bragelman (2018) were among the first to devote significant effort to fully describe and characterize the complexity of videos. In the process of creating the Video Complexity Framework for the present study (i.e. Figure 2), numerous references were reviewed and yet it was difficult to find a comprehensive list of video characteristics. Beyond finding a comprehensive list, it was also challenging to find descriptions of the actual videos researchers used. Some researchers were explicit about whether the video was self-created or a stock video (e.g. Beisiegel et al., 2018), others included details about video length (e.g. Jilk, 2016), and some included reference to whether videos were edited or unedited (e.g. Mitchell \& Marin, 2015). Despite these descriptors, prior to this work, few researchers had attempted to fully characterize the videos used in many studies in teacher education. Consequently, we encourage researchers to be more explicit in describing the complexity of the videos they use in their practice. We provide the Video Complexity Framework as a tool researchers and teacher educators can reference and use to both select video and describe video in their research. We believe that increased transparency around the characteristics and complexities of videos used in teacher education will better enable other researchers to use videos that may be more appropriate for their specific needs.

Finally, we urge teacher educators who plan to use video and researchers who conduct studies that incorporate video to further consider the complexity characteristics that may be most meaningful for understanding the contents of a video clip in relation to a particular audience. Through our research, we questioned whether or not intrinsic load dimensions and extraneous load dimensions (i.e. Paas, Renkl, \& Sweller, 2003; Superfine \& Bragelman, 2018; Sweller, van Merriënboer \& Paas, 2019) should be considered together (as was done for this analysis), or if they should be considered separately. As an example, there could be a video clip with a student explaining thinking that is very simple and easy to understand, yet the video could have audio and visual issues that would increase the complexity score. Similarly, it would be possible to have a video with very clear audio and visual and one student who explains his thinking in a complicated way that was difficult to decipher. It is possible that the two videos could have similar complexity scores, yet the contents of the videos would be very different. In our analysis, we did not account for these possible differences, but encourage other researchers to consider how they may tease apart these nuances to better describe the complexity of videos.

\section{CONCLUSION}

The video club process provided a context in which the complexity of content videos was analyzed in relation to the length of time particular videos were discussed. We used the video club structure to better understand which videos teachers selected to discuss from a larger set (i.e. discussed 22 of the 34 videos). Because video use is common internationally for teacher learning (e.g. Brophy, 2003; Christ, Arya, \& Chiu, 2017; Goldman, Pea, Barron, \& Derry, 2014), beyond specific use in a video club, it is important that attention is given to the complexity of the videos used. Although we did not find a definite answer to the relationship between video complexity and the amount of time teachers discussed a particular video, findings provide insight about the characteristics of videos that teachers discussed. Video is a powerful tool for teacher learning and the Video Complexity Framework provides teacher 
educators and researchers with a tool to consider the complexity of the videos they use during teacher learning experiences.

\section{ACKNOWLEDGEMENTS}

This work was supported by the Idaho State Department of Education under grant number 18-3554.

\section{REFERENCES}

Ball, D. L. (1996). Teacher learning and the mathematics reforms: What we think we know and what we need to learn. Phi Delta Kappan, 77, 500-508. Retrieved from https://journals.sagepub.com/home/pdk

Barab, S. A., \& Duffy, T. M. (2000). From practice fields to communities of practice. In D. H. Jonassen \& S. M. Land (Eds.), Theoretical foundation of learning environments (pp. 25-55). Mahwah, NJ: Lawrence Erlbaum Associates.

Beisiegel, M., Mitchell, R., \& Hill, H. C. (2018). The design of video-based professional development: An exploratory experiment intended to identify effective features. Journal of Teacher Education, 69(1), 69-89. https:/ / doi.org/10.1177/0022487117705096

Borko, H., Jacobs, J., Eiteljorg, E., \& Pittman, M. E. (2008). Video as a Tool for Fostering Productive Discussions in Mathematics Professional Development. Teaching and Teacher Education, 24(2), 417-436. https:// doi.org/10.1016/j.tate.2006.11.012

Borko, H., Virmani, R., Khachatryan, E., \& Mangram, C. (2014). The roles of video-based discussions in professional development and the preparation of professional development leaders. In B. D. Calandra \& P. Rich (Eds.), Digital video for teacher education: Research and practice (pp. 89-108). Philadelphia, RA: Routledge. https:/ / doi.org/10.4324/9781315871714

Brophy, J. E. (2003). Teaching Problem Students. New York, NY: Guilford Press.

Choppin, J. (2011). Learned adaptations: Teachers' understanding and use of curriculum resources. Journal of Mathematics Teacher Education, 14(5), 331-353. https:/ / doi.org/10.1007/s10857-011-9170-3

Christ, T., Arya, P., \& Chiu, M. M. (2017). Video use in teacher education: An international survey of practices. Teaching and Teacher Education, 63, 22-35. https:/ / doi.org/10.1016/j.tate.2016.12.005

Coles, A. (2013a). Using video for professional development: the role of the discussion facilitator. Journal of Mathematics Teacher Education, 16(3), 165-184. https:/ / doi.org/10.1007/s10857-012-9225-0

Corbin, J. \& Strauss, A. (2007). Basics of qualitative research: Techniques and procedures for developing grounded theory (3rd ed.). Thousand Oaks, CA: Sage. https:// doi.org/10.4135/9781452230153

Denzin, N. K., \& Lincoln Y.S. (Eds.). (2003). Collecting and interpreting qualitative materials (2nd ed.) Thousand Oaks, CA: Sage.

Goldman, R., Pea, R., Barron, B., \& Derry, S. J. (2014). Video Research in the Learning Sciences. New York: Routledge. https:/ / doi.org/10.4324/9780203877258

Grossman, P., Cohen, J., Ronfeldt, M., \& Brown, L. (2014). The Test Matters: The Relationship Between Classroom Observation Scores and Teacher Value Added on Multiple Types of Assessment. Educational Researcher, 43(6), 293-303. https:/ / doi.org/10.3102/0013189X14544542

Jacobs, V. R., Lamb, L. L. C., \& Philipp, R. A. (2010). Professional noticing of children's mathematical thinking. Journal for Research in Mathematics Education, 41(2), 169-202.

Jilk, L. (2016). Supporting teacher noticing of students' mathematical strengths. Mathematics Teacher Educator, 4(2), 188-199. https:// doi.org/10.5951/mathteaceduc.4.2.0188

Kang, H. \& van Es, E. (2018) Articulating design principles for productive use of videos to facilitate professional learning toward ambitious teaching. Journal of Teacher Education, 70(3), 237-250. https:/ / doi.org/10.1177/0022487118778549

Kersting, N. B., Sutton, T., Kalinec-Craig, C., Stoehr, K. J., Heshmati, S., Lozano, G., \& Stigler, J. W. (2016). Further exploration of the classroom video analysis (CVA) instrument as a measure of usable knowledge for teaching mathematics: taking a knowledge system perspective. ZDM - International Journal on Mathematics Education. 48(1-2), 97-109. https:/ / doi.org/10.1007/s11858-015-0733-0

Lee, H., Plass, J. L., \& Homer, B. D. (2006). Optimizing cognitive load for learning from computer-based science simulations. Educational Psychologist, 902-913. https:/ / doi.org/10.1037/0022-0663.98.4.902

Luna, M. \& Sherin, M. (2017). Using a video club design to promote teacher attention to students' ideas in science. Teaching and Teacher Education, 66, 282-294. https:/ / doi.org/10.1016/j.tate.2017.04.019 
Mason, J. (2002). Researching your own practice: The discipline of noticing. New York: Routledge. https://doi.org/10.4324/9780203471876

Mason, J. (2011). Noticing: Roots and branches. In M. G. Sherin, V. R. Jacobs, \& R. A. Philipp (Eds.), Mathematics teacher noticing: Seeing through teachers' eyes (pp. 35-50). New York: Routledge. https:/ / doi.org/10.4324/9780203832714

Mitchell, R. \& Marin, K. (2015). Examining the use of a structured analysis framework to support prospective teacher noticing. Journal of Mathematics Teacher Education, 18(6), 551-575. https://doi.org/10.1007/s10857014-9294-3

Paas, F., Renkl, A., \& Sweller, J. (2003). Cognitive load theory and instructional design: Recent developments. Educational psychologist, 38(1), 1-4. https:/ / doi.org/10.1207/S15326985EP3801_1

Seago, N. (2004). Using video as an object of inquiry for mathematics teaching and learning. In J. Brophy (Ed.), Advances in research on teaching: Vol. 10. Using video in teacher education (pp. 259-286). Oxford, UK: Elsevier. https:/ / doi.org/10.1016/S1479-3687(03)10010-7

Sherin, B. L. \& Star, J. R. (2011). Reflections on the study of teacher noticing. In M. G. Sherin, V. R. Jacobs, \& R. A. Philipp (Eds.), Mathematics teacher noticing: Seeing through teachers' eyes (pp. 66-78). New York: Routledge. https:// doi.org/10.4324/9780203832714

Sherin, M. \& Dyer, E. (2017). Mathematics teachers' self-captured video and opportunities for learning. Journal of Mathematics Teacher Education, 20, 477-495. https:/ / doi.org/10.1007/s10857-017-9383-1

Sherin, M. G. \& Han, S. Y. (2004). Teacher learning in the context of a video club. Teaching and Teacher Education, 20(2), 163-183. https:/ / doi.org/10.1016/j.tate.2003.08.001

Sherin, M. G. \& Russ, R. (2015). Teacher noticing via video: The role of interpretive frames. In B. Calandra \& P. Rich (Eds.) Digital video for teacher education: Research and practice. New York: Routledge. https:// doi.org/10.4324/9781315871714

Sherin, M. G. \& van Es, E. A. (2009). Effects of video club participation on teachers' professional vision. Journal of Teacher Education, 60, 20-37. https:/ / doi.org/10.1177/0022487108328155

Sherin, M. G., Linsenmeier, K. A., \& van Es, E. A. (2009). Selecting video clips to promote mathematics teachers' discussion of student thinking. Journal of Teacher Education, 60, 213-230. https:/ / doi.org/10.1177/0022487109336967

Superfine, A. \& Bragelman, J. (2018). Analyzing the Impact of Video Representation Complexity on Preservice Teacher Noticing of Children's Thinking. Eurasia Journal of Mathematics, Science and Technology Education, 14(11). https:/ / doi.org/10.29333/ ejmste/99501

Sweller, J. (2003). Evolution of human cognitive architecture. In B. H. Hoss (Ed.), The psychology of learning and motivation: Advances in research and theory (pp. 216-266). San Diego: CA: Academic Press. https:/ / doi.org/10.1016/S0079-7421(03)01015-6

Sweller, J., van Merriënboer, J. J., \& Paas, F. (2019). Cognitive architecture and instructional design: 20 years later. Educational Psychology Review, 1-32. https:/ / doi.org/10.1007/s10648-019-09465-5

Taylor, J. A., Roth, K., Wilson, C. Stuhlsatz, M., \& Tipton, E. (2016). The effect of an analysis-of-practice, videocasebased, teacher professional development program on elementary students' science achievement. Intervention, Evaluation, and Policy Studies, 10, 241-271. https:/ / doi.org/10.1080/19345747.2016.1147628

van Es, E. A. \& Sherin, M. G. (2008). Mathematics teachers' “learning to notice” in the context of a video club. Teaching and Teacher Education, 24, 244-276. https:/ / doi.org/10.1016/j.tate.2006.11.005

van Es, E. A. (2011). A framework for learning to notice student thinking. In M. G. Sherin, V. R. Jacobs, \& R. A. Philipp (Eds.), Mathematics teacher noticing: Seeing through teachers' eyes (pp. 134-151). New York: Routledge. https://doi.org/10.4324/9780203832714

van Es, E. A., Cashen, M., Barnhart, T., \& Auger, A. (2017). Learning to notice mathematics instruction: Using video to develop preservice teachers' vision of ambitious pedagogy. Cognition E Instruction, 35(3), 165-187. https:/ / doi.org/10.1080/07370008.2017.1317125

van Es, E. A., Tunney, J., Goldsmith, L. T., \& Seago, N. (2014). A framework for the facilitation of teachers' analysis of video. Journal of Teacher Education, 65(4), 340-356. https:/ / doi.org/10.1177/0022487114534266

Walkoe, J. (2015). Exploring teacher noticing of student algebraic thinking in a video club. Journal of Mathematics Teacher Education, 18(6), 523-550. https:/ / doi.org/10.1007/s10857-014-9289-0

Walkoe, J., Sherin, M. G., \& Elby, A. (2019). Video tagging as a window into teacher noticing. Journal of Mathematics Teacher Education. https:/ / doi.org/10.1007/s10857-019-09429-0 


\section{APPENDIX A}

\section{Changes from Superfine and Bragelman (2018) to Video Complexity Framework}

\begin{tabular}{|c|c|c|c|}
\hline Complexity Characteristic & $\begin{array}{l}\text { Castro Superfine \& } \\
\text { Bragelman }\end{array}$ & $\begin{array}{l}\text { Video Complexity } \\
\text { Framework (text indicates a } \\
\text { change to the text provided) }\end{array}$ & Rationale for Change \\
\hline \multicolumn{4}{|l|}{ Intrinsic Load Dimensions } \\
\hline $\begin{array}{l}\text { Depth of Enacted Task } \\
\text { The number of foci being } \\
\text { discussed/argued, number of } \\
\text { strategies presented/discussed, } \\
\text { use of multiple representations }\end{array}$ & $\begin{array}{l}\text { (0) } 1 \text { topic, strategy being } \\
\text { discussed; multiple } \\
\text { representations not } \\
\text { present; no errors or } \\
\text { misconceptions in student } \\
\text { thinking } \\
\text { (1) Several strategies being } \\
\text { discussed; multiple } \\
\text { representations used; and } \\
\text { error or non-standard } \\
\text { strategy present }\end{array}$ & $\begin{array}{l}\text { Same Definition; Same } \\
\text { complexity values }\end{array}$ & \\
\hline $\begin{array}{l}\text { Clarity of Child Thinking } \\
\text { How easy is it to understand } \\
\text { the children's thinking shown } \\
\text { in the video }\end{array}$ & $\begin{array}{l}\text { (0) Children's thinking } \\
\text { transparent; single } \\
\text { interpretation obvious } \\
\text { (1) Children's thinking not } \\
\text { transparent }\end{array}$ & $\begin{array}{l}\text { Same Definition; Same } \\
\text { complexity values }\end{array}$ & \\
\hline $\begin{array}{l}\text { Teacher Participation } \\
\text { How the teacher asks } \\
\text { questions - do the questions } \\
\text { prime PSTs to attend to CMT }\end{array}$ & $\begin{array}{l}\text { (0) Yes, teacher asks } \\
\text { questions related to CMT } \\
\text { (1) No, teacher asks } \\
\text { questions related to non- } \\
\text { CMT issues }\end{array}$ & $\begin{array}{l}\text { Same Definition; } \\
(0) \text { No questions asked } \\
(0.5) \text { Teacher asks questions } \\
\text { related to children' } \\
\text { mathematical thinking } \\
(0.5) \text { Teacher asks questions } \\
\text { related to issues that are not } \\
\text { children's mathematical } \\
\text { thinking } \\
(1) \text { Teacher asks questions both } \\
\text { about children's mathematical } \\
\text { thinking and about topics that } \\
\text { are not children's } \\
\text { mathematical thinking }\end{array}$ & $\begin{array}{l}\text { We considered asking questions to } \\
\text { add a level of complexity (i.e. } \\
\text { element of interactivity; Sweller, } \\
\text { 2003) to the video. Thus, no } \\
\text { questions asked did not add } \\
\text { complexity. We considered } \\
\text { questions with one focus (e.g. related } \\
\text { to children's mathematical thinking } \\
\text { or not related to children's } \\
\text { mathematical thinking) to pose } \\
\text { similar degrees of complexity } \\
\text { because of the possible variations } \\
\text { that could occur with questions. We } \\
\text { did not believe we could determine } \\
\text { which type of question would add to } \\
\text { the complexity. However, we } \\
\text { contend that if there were questions } \\
\text { about children's mathematical } \\
\text { thinking and questions that were } \\
\text { about topics that were not children's } \\
\text { mathematical thinking that the video } \\
\text { would then be more complex } \\
\text { because viewers would have to } \\
\text { decipher between questions } \\
\text { pertinent to children's mathematical } \\
\text { thinking and those that were not. }\end{array}$ \\
\hline $\begin{array}{l}\text { Sequential Moments of CMT } \\
\text { The number of times CMT } \\
\text { occurs in a video }\end{array}$ & $\begin{array}{l}\text { (0) } 1 \text { moment of CMT } \\
\text { (1) Several moments of } \\
\text { CMT }\end{array}$ & $\begin{array}{l}\text { Moments of Children's } \\
\text { mathematical Thinking } \\
\text { (0) Children take turns } \\
\text { expressing their mathematical } \\
\text { thing with one child talking at } \\
\text { a time }\end{array}$ & $\begin{array}{l}\text { The two categories (i.e. Sequential } \\
\text { and Simultaneous Moments) were } \\
\text { combined because we found it } \\
\text { difficult to determine "the number of } \\
\text { times children's mathematical } \\
\text { thinking occurs in a video" }\end{array}$ \\
\hline $\begin{array}{l}\text { Simultaneous Moments of } \\
\text { CMT } \\
\text { Two or more children discuss } \\
\text { CMT simultaneously }\end{array}$ & $\begin{array}{l}\text { (0) Children take turns } \\
\text { expressing their } \\
\text { mathematical thinking } \\
\text { (1) Multiple children } \\
\text { discuss CMT } \\
\text { simultaneously }\end{array}$ & $\begin{array}{l}\text { (1) Multiple children discuss } \\
\text { children's mathematical } \\
\text { thinking simultaneously }\end{array}$ & $\begin{array}{l}\text { (Superfine \& Bragelman, 2018, p. 5). } \\
\text { The new descriptor emphasizes the } \\
\text { simultaneous nature of discussion as } \\
\text { the complexity indicator }\end{array}$ \\
\hline $\begin{array}{l}\text { Types of CMT in Video } \\
\text { CMT occurs verbally or } \\
\text { visually }\end{array}$ & $\begin{array}{l}\text { (0) Audio or visual CMT } \\
\text { (1) Both audio and visual }\end{array}$ & $\begin{array}{l}\text { Same Definition; Same } \\
\text { complexity values }\end{array}$ & \\
\hline
\end{tabular}




\begin{tabular}{|c|c|c|c|}
\hline \multicolumn{4}{|l|}{ Extraneous Load Dimensions } \\
\hline $\begin{array}{l}\text { Non-CMT Moments } \\
\text { Moments that can be attended } \\
\text { to that are not CMT }\end{array}$ & $\begin{array}{l}\text { (0) One moment of non- } \\
\text { CMT } \\
\text { (1) Several moments of } \\
\text { non-CMT }\end{array}$ & $\begin{array}{l}\text { Same Definition; } \\
(0) \text { None } \\
\text { (0.5)One moment of non- } \\
\text { children's mathematical } \\
\text { thinking } \\
\text { (1) Several moments of non- } \\
\text { children's mathematical } \\
\text { thinking }\end{array}$ & $\begin{array}{l}\text { We considered there to be three } \\
\text { options for non-CMT moments: } \\
\text { None, one, several. We considered } \\
\text { "none" to not add to complexity, but } \\
\text { we considered one moment to add to } \\
\text { the complexity because it meant } \\
\text { increased mental effort to decipher } \\
\text { the situation (Sweller, 2003). }\end{array}$ \\
\hline $\begin{array}{l}\text { Visual-Verbal Noise } \\
\text { Extraneous information in the } \\
\text { videos PSTs must attend to }\end{array}$ & $\begin{array}{l}\text { (0) One channel of load- } \\
\text { visual or audio } \\
\text { (1) Both channels }\end{array}$ & $\begin{array}{l}\text { Same Definition: } \\
\text { (0) No extraneous load } \\
\text { (0.5) One channel has } \\
\text { extraneous load - visual or } \\
\text { audio } \\
\text { (1) Both channels have } \\
\text { extraneous load - visual and } \\
\text { audio }\end{array}$ & $\begin{array}{l}\text { We considered there to be three } \\
\text { options for visual-verbal noise: none, } \\
\text { one channel, both channels. If one } \\
\text { channel had extraneous load, then } \\
\text { we considered that to add to the } \\
\text { complexity because it meant } \\
\text { increased mental effort to decipher } \\
\text { the situation (Sweller, 2003). }\end{array}$ \\
\hline $\begin{array}{l}\text { Audio Clarity } \\
\text { Clarity of the auditory aspects } \\
\text { of the video }\end{array}$ & $\begin{array}{l}\text { Not Included in Superfine } \\
\text { \& Bragelman (2018) } \\
\text { Framework }\end{array}$ & $\begin{array}{l}\text { (0) No Issues } \\
(0.5) \text { Minor Issues } \\
\text { (1) Major Issues }\end{array}$ & $\begin{array}{l}\text { We considered issues with whether } \\
\text { or not audio fully functioned to be } \\
\text { contributors to the extraneous load } \\
\text { because it would demand extra } \\
\text { mental effort to with respect to } \\
\text { presentation (Sweller, 2003). }\end{array}$ \\
\hline $\begin{array}{l}\text { Video Clarity } \\
\text { Clarity of the visual aspects of } \\
\text { the video (i.e. blurry, clear) }\end{array}$ & $\begin{array}{l}\text { Not Included in Superfine } \\
\text { \& Bragelman (2018) } \\
\text { Framework }\end{array}$ & $\begin{array}{l}\text { (0)No Issues } \\
\text { (0.5) Minor Issues } \\
\text { (1) Major Issues }\end{array}$ & $\begin{array}{l}\text { We considered issues with whether } \\
\text { or not video fully functioned to be } \\
\text { contributors to the extraneous load } \\
\text { because it would demand extra } \\
\text { mental effort to with respect to } \\
\text { presentation (Sweller, 2003). }\end{array}$ \\
\hline
\end{tabular}




\section{APPENDIX B}

\section{Coding Example for One Video}

\begin{tabular}{|c|c|c|c|c|c|}
\hline $\begin{array}{l}\text { Complexity } \\
\text { Characteristic }\end{array}$ & Description & Codes & $\begin{array}{l}\text { Complexity } \\
\text { Value } \\
\text { Possible } \\
\end{array}$ & $\begin{array}{l}\text { Complexity } \\
\text { Value } \\
\text { Assigned } \\
\end{array}$ & $\begin{array}{l}\text { Rationale for } \\
\text { Complexity Value }\end{array}$ \\
\hline \multicolumn{6}{|c|}{ Qualitative Aspects } \\
\hline $\begin{array}{l}\text { Summary } \\
\text { Description }\end{array}$ & $\begin{array}{l}\text { Ten word or less } \\
\text { description of the } \\
\text { video }\end{array}$ & Written narrative & $\begin{array}{l}\text { No } \\
\text { complexity } \\
\text { value }\end{array}$ & $\begin{array}{l}\text { Students (four) } \\
\text { are discussing } \\
\text { adding } 19 \text { four } \\
\text { times; one } \\
\text { student is } \\
\text { questioning the } \\
\text { other student. }\end{array}$ & \\
\hline $\begin{array}{l}\text { Participation } \\
\text { Structure }\end{array}$ & $\begin{array}{l}\text { Focus of arrangement } \\
\text { of students during the } \\
\text { lesson (could have } \\
\text { more than one foci) }\end{array}$ & $\begin{array}{l}\text { Whole-class } \\
\text { Pairs } \\
\text { Individual } \\
\text { Combination of Elements } \\
\text { Student Work Only }\end{array}$ & $\begin{array}{l}\text { No } \\
\text { complexity } \\
\text { value }\end{array}$ & $\begin{array}{l}\text { Combination of } \\
\text { Elements, } \\
\text { Student Work }\end{array}$ & \\
\hline & & $\begin{array}{l}\text { Teacher } \\
\text { Student Work }\end{array}$ & & & \\
\hline $\begin{array}{l}\text { Enhanced } \\
\text { Video }\end{array}$ & $\begin{array}{l}\text { Graphical recreation or } \\
\text { enlarged image of } \\
\text { student work }\end{array}$ & $\begin{array}{l}\text { Enhanced } \\
\text { Not Enhanced }\end{array}$ & $\begin{array}{l}\text { No } \\
\text { complexity } \\
\text { value }\end{array}$ & Not Enhanced & \\
\hline $\begin{array}{l}\text { Student } \\
\text { Presence }\end{array}$ & $\begin{array}{l}\text { Extent to which the } \\
\text { same child appears in } \\
\text { multiple videos }\end{array}$ & $\begin{array}{l}\text { Yes (if so, list video numbers) } \\
\text { No }\end{array}$ & $\begin{array}{l}\text { No } \\
\text { complexity } \\
\text { value }\end{array}$ & $\begin{array}{l}\text { Yes (student } \\
\text { was in two } \\
\text { other videos) }\end{array}$ & \\
\hline \multicolumn{6}{|c|}{ Extraneous Complexity Factors } \\
\hline Audio Clarity & $\begin{array}{l}\text { Clarity of the auditory } \\
\text { aspects of the video }\end{array}$ & $\begin{array}{l}\text { No Issues } \\
\text { Minor Issues } \\
\text { Major Issues }\end{array}$ & $\begin{array}{l}(0) \\
(0.5) \\
(1)\end{array}$ & $(0)$ & $\begin{array}{l}\text { There are no issues with } \\
\text { the audio clarity }\end{array}$ \\
\hline Video Clarity & $\begin{array}{l}\text { Clarity of the visual } \\
\text { aspects of the video } \\
\text { (i.e. blurry, clear) }\end{array}$ & $\begin{array}{l}\text { No Issues } \\
\text { Minor Issues } \\
\text { Major Issues } \\
\end{array}$ & $\begin{array}{l}(0) \\
(0.5) \\
(1)\end{array}$ & $(0.5)$ & $\begin{array}{l}\text { Video moves too quickly } \\
\text { at one point }\end{array}$ \\
\hline $\begin{array}{l}\text { Non-Children' } \\
\text { Mathematical } \\
\text { Thinking } \\
\text { Moments }\end{array}$ & $\begin{array}{l}\text { Moments that can be } \\
\text { attended to that are not } \\
\text { children's } \\
\text { mathematical thinking }\end{array}$ & $\begin{array}{l}\text { None } \\
\text { One moment of non-children's } \\
\text { mathematical thinking } \\
\text { Several moment of non- } \\
\text { children's mathematical } \\
\text { thinking }\end{array}$ & $\begin{array}{l}(0) \\
(0.5) \\
(1)\end{array}$ & $(0)$ & $\begin{array}{l}\text { There were no instances } \\
\text { of non-mathematical } \\
\text { thinking. The video } \\
\text { focused on the children's } \\
\text { mathematical thinking } \\
\text { for the entire duration of } \\
\text { the clip. }\end{array}$ \\
\hline $\begin{array}{l}\text { Visual-Verbal } \\
\text { Noise }\end{array}$ & $\begin{array}{l}\text { Extraneous } \\
\text { Information in the } \\
\text { videos }\end{array}$ & $\begin{array}{l}\text { No extraneous load } \\
\text { One channel have extraneous } \\
\text { load-visual or audio } \\
\text { Both channels have extraneous } \\
\text { load- visual and audio }\end{array}$ & $\begin{array}{l}(0) \\
(0.5) \\
(1)\end{array}$ & (1) & $\begin{array}{l}\text { There were other } \\
\text { students talking in the } \\
\text { background (audio) } \\
\text { which could be } \\
\text { conceived as distracting; } \\
\text { there were students } \\
\text { walking in the } \\
\text { background (visual) of } \\
\text { the video while the focal } \\
\text { students were discussing } \\
\text { their thinking. }\end{array}$ \\
\hline \multicolumn{6}{|c|}{ Intrinsic Complexity Factors } \\
\hline $\begin{array}{l}\text { Depth of } \\
\text { Enacted Task }\end{array}$ & $\begin{array}{l}\text { The number of foci } \\
\text { being discussed / } \\
\text { argued, number of } \\
\text { strategies presented / } \\
\text { discussed, use of } \\
\text { multiple } \\
\text { representations }\end{array}$ & $\begin{array}{l}\text { One topic or strategy } \\
\text { discussed; multiple } \\
\text { representations not present } \\
\text { Several strategies being } \\
\text { discussed; multiple } \\
\text { representations used or } \\
\text { strategies present }\end{array}$ & $(1)$ & $(1)$ & $\begin{array}{l}\text { Two strategies were } \\
\text { discussed for adding } 19 \\
\text { four times. One student } \\
\text { had discarded difficult } \\
\text { numbers to make the } \\
\text { problem easier to add, } \\
\text { while another coached } \\
\text { that student to break } \\
\text { down the } 19 \text { s so they can } \\
\text { be added more easily. }\end{array}$ \\
\hline
\end{tabular}




\begin{tabular}{|c|c|c|c|c|c|}
\hline $\begin{array}{l}\text { Errors of } \\
\text { Student } \\
\text { Thinking }\end{array}$ & $\begin{array}{l}\text { Presence of student } \\
\text { misconception or error }\end{array}$ & $\begin{array}{l}\text { No error in thinking } \\
\text { Error present in thinking }\end{array}$ & $\begin{array}{l}(0) \\
(1)\end{array}$ & (1) & $\begin{array}{l}\text { There was an error in } \\
\text { student thinking. One } \\
\text { student discarded the } 9 \mathrm{~s} \\
\text { in the four } 19 \mathrm{~s} \text { and just } \\
\text { added the tens to come } \\
\text { with } 40 . .\end{array}$ \\
\hline $\begin{array}{l}\text { Clarity of Chilc } \\
\text { Thinking }\end{array}$ & $\begin{array}{l}\text { Feasibility to } \\
\text { understand the child's } \\
\text { thinking in the video }\end{array}$ & $\begin{array}{l}\text { Child's thinking is transparent, } \\
\text { single interpretation is obvious } \\
\text { Child's thinking is not } \\
\text { transparent }\end{array}$ & $\begin{array}{l}\text { (0) } \\
(1)\end{array}$ & (0) & $\begin{array}{l}\text { The student's thinking } \\
\text { was expressed clearly. }\end{array}$ \\
\hline $\begin{array}{l}\text { Teacher } \\
\text { Participation }\end{array}$ & $\begin{array}{l}\text { Extent to which teacher } \\
\text { questions prime } \\
\text { attention toward } \\
\text { children's } \\
\text { mathematical thinking }\end{array}$ & $\begin{array}{l}\text { r No questions asked } \\
\text { Teacher asks questions related } \\
\text { to children's mathematical } \\
\text { thinking } \\
\text { Teacher asks questions related } \\
\text { to issues that are not children's } \\
\text { mathematical thinking } \\
\text { Teacher asks questions both } \\
\text { about children's mathematical } \\
\text { thinking and about topics that } \\
\text { are not children's' } \\
\text { mathematical thinking }\end{array}$ & $\begin{array}{l}(0) \\
(0.5) \\
(0.5)\end{array}$ & $\begin{array}{l}(0) \\
\end{array}$ & $\begin{array}{l}\text { The teacher did not ask } \\
\text { any questions during the } \\
\text { clip. }\end{array}$ \\
\hline $\begin{array}{l}\text { Moments of } \\
\text { Children's } \\
\text { Mathematical } \\
\text { Thinking }\end{array}$ & $\begin{array}{l}\text { Number of times and } \\
\text { number of children } \\
\text { discussion children's } \\
\text { mathematical thinking }\end{array}$ & $\begin{array}{l}\text { Children take turns expressing } \\
\text { their mathematical thinking } \\
\text { with one child talking at a time } \\
\text { Multiple children discuss } \\
\text { children's mathematical } \\
\text { thinking simultaneously }\end{array}$ & (1) & (1) & $\begin{array}{l}\text { In the clip, in a group of } \\
4 \text {, one student talks } \\
\text { another student through } \\
\text { a math problem with } \\
\text { several interjections from } \\
\text { two other children in the } \\
\text { group. }\end{array}$ \\
\hline $\begin{array}{l}\text { Types of } \\
\text { Children's } \\
\text { Mathematical } \\
\text { Thinking }\end{array}$ & $\begin{array}{l}\text { Extent to which } \\
\text { children's } \\
\text { mathematical thinking } \\
\text { is expressed verbally or } \\
\text { in writing }\end{array}$ & $\begin{array}{l}\text { Audio or visual } \\
\text { Audio and visual } \\
\text { r }\end{array}$ & $\begin{array}{l}(0) \\
(1)\end{array}$ & (1) & $\begin{array}{l}\text { Student's thinking was } \\
\text { expressed verbally and in } \\
\text { writing in the clip. }\end{array}$ \\
\hline
\end{tabular}

http://www.ejmste.com 